Key Words:

Electrolysis

Hydrogen

Sulfur Dioxide

Hybrid Sulfur

Retention: Permanent

\title{
FY08 Membrane Characterization Report for Hybrid Sulfur Electrolyzer
}

\author{
H. R. Colon-Mercado \\ M. C. Elvington \\ D. T. Hobbs
}

September 2008

Savannah River Nuclear Solutions, LLC

Savannah River National Laboratory

Aiken, SC 29808
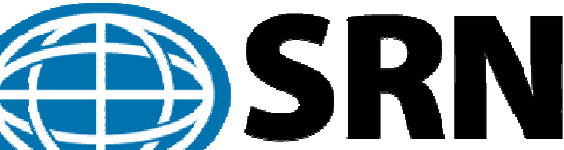

SAVANNAH RIVER NATIONAL LABORATORY 


\section{Contract No:}

This document was prepared in conjunction with work accomplished under Contract No. DE-AC09-08SR22470 with the U.S. Department of Energy.

\section{Disclaimer:}

This work was prepared under an agreement with and funded by the U.S. Government. Neither the U. S. Government or its employees, nor any of its contractors, subcontractors or their employees, makes any express or implied: 1. warranty or assumes any legal liability for the accuracy, completeness, or for the use or results of such use of any information, product, or process disclosed;

or 2. representation that such use or results of such use would not infringe privately owned rights; or 3. endorsement or recommendation of any specifically identified commercial product, process, or service. Any views and opinions of authors expressed in this work do not necessarily state or reflect those of the United States Government, or its contractors, or subcontractors.

\section{Printed in the United States of America}

Prepared For

U.S. Department of Energy 


\section{APPROVALS}

H. C. Colon-Mercado, Author, Energy Security

Date

M. C. Elvington, Author, Environmental \& Chemical Processing Technology

Date

D. T. Hobbs, Author, Environmental \& Chemical Processing Technology

Date

W. A. Summers, Program Manager, Energy Security

Date 


\section{TABLE OF CONTENTS}

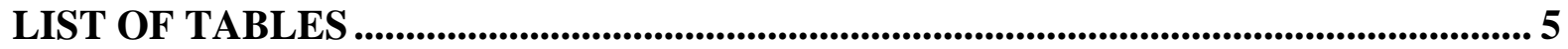

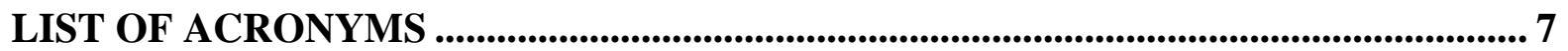

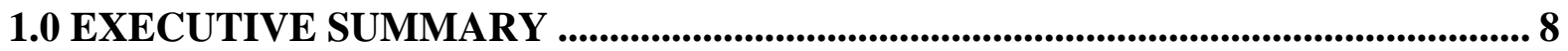

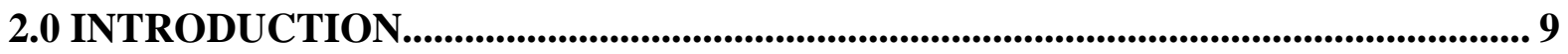

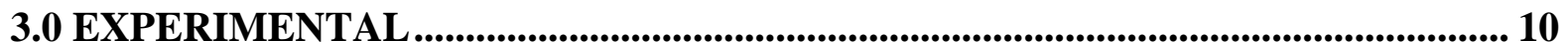

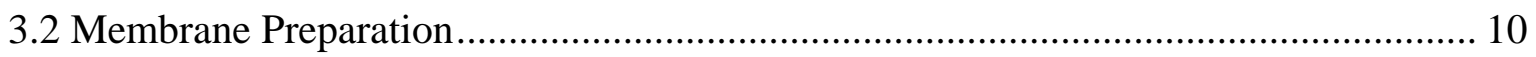

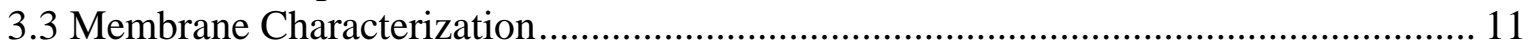

4.1 Sulfur Dioxide Transport at rest conditions ...................................................... 16

4.2 Sulfur Dioxide Transport Under applied potential .................................................. 23

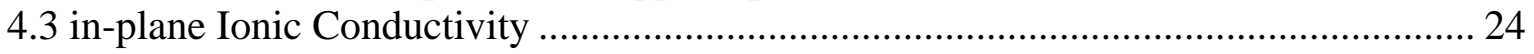

5.0 CONCLUSIONS AND RECOMMENDATIONS................................................. 27

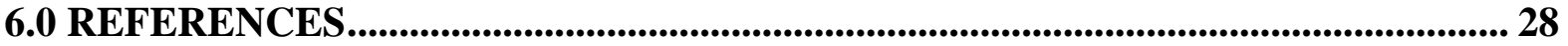




\section{LIST OF TABLES}

Table 1. Evaluated commercial membranes .........................................10

Table 2. Evaluated experimental membranes .......................................11

Table 3. $\mathrm{SO}_{2}$ transport coefficient through the tested membranes immersed in $30 \mathrm{wt} \%$ and 50 wt \% $\mathrm{H}_{2} \mathrm{SO}_{4}$ saturated with $\mathrm{SO}_{2}$ at room temperature. Working electrode set at $1040 \mathrm{mV}$ vs. SHE Comparison of diffusion coefficient and ionic resistance in evaluated membranes..............................................23

Table 4. $\mathrm{SO}_{2}$ transport coefficient conductivity and selectivity of experimental membranes tested at room temperature conditions.............................25 


\section{LIST OF FIGURES}

Figure 1. Simplified schematic of the $\mathrm{SO}_{2}$ transport characterization cell.............12

Figure 2. Simplified schematic of the modified $\mathrm{SO}_{2}$ transport characterization cell..14

Figure 3. Simplified schematic of the ionic conductivity characterization cell........15

Figure 4. $\mathrm{SO}_{2}$ transport through PFSA membranes immersed in (a) $30 \mathrm{wt} \%$ and (b) 50 wt\% $\mathrm{H}_{2} \mathrm{SO}_{4}$ saturated with $\mathrm{SO}_{2}$ at room temperature. Working electrode set at $1040 \mathrm{mV}$ vs. SHE...............................................19

Figure 5. $\mathrm{SO}_{2}$ transport through commercial membranes immersed in (a) $30 \mathrm{wt} \%$ and (b) 50 wt\% $\quad \mathrm{H}_{2} \mathrm{SO}_{4}$ saturated with $\mathrm{SO}_{2}$ at different temperatures. Working electrode set at $1040 \mathrm{mV}$ vs.SHE...............................20

Figure 6: $\mathrm{SO}_{2}$ transport through experimental membranes immersed in $30 \mathrm{wt} \%$ $\mathrm{H}_{2} \mathrm{SO}_{4}$ saturated with $\mathrm{SO}_{2}$ at room temperature. Working electrode set at $1040 \mathrm{mV}$ vs. SHE.............................................................21

Figure 7. $\mathrm{SO}_{2}$ transport through PFSA experimental membranes immersed in 30 wt $\% \mathrm{H}_{2} \mathrm{SO}_{4}$ saturated with $\mathrm{SO}_{2}$ at room temperature. Working electrode set at $1040 \mathrm{mV}$ vs. SHE...................................................22

Figure 8. $\mathrm{SO}_{2}$ transport through non-PFSA experimental membranes immersed in $30 \mathrm{wt} \% \mathrm{H}_{2} \mathrm{SO}_{4}$ saturated with $\mathrm{SO}_{2}$ at room temperature. Working electrode set at $1040 \mathrm{mV}$ vs. SHE........................................22

Figure 9. Typical behavior representing the effect of an applied current across the membrane on the $\mathrm{SO}_{2}$ transport through a cationic membrane immersed in 30 wt\% $\mathrm{H}_{2} \mathrm{SO}_{4}$ saturated with $\mathrm{SO}_{2}$ at room temperature. Working electrode set at $1040 \mathrm{mV}$ vs. SHE............................................24

Figure 10. Ion conductivity of the membrane samples as a function of temperature and acid concentration for (a) fluorocarbon type membranes and (b) hydrocarbon type membranes..............................................26 


\section{LIST OF ACRONYMS}

$\begin{array}{ll}\text { BAS } & \text { Bioanalytical Systems } \\ \text { CCE } & \text { Catalyst Coated Electrode } \\ \text { CCM } & \text { Catalyst Coated Membrane } \\ \text { CV } & \text { Cyclic Voltammogram } \\ \text { DI-water } & \text { Deionized water } \\ \text { DM } & \text { Direct Methanol } \\ \text { EIS } & \text { Electrochemical Impedance Spectroscopy } \\ \text { EW } & \text { Equivalent Weight } \\ \text { HyS } & \text { Hybrid Sulfur } \\ \text { LSV } & \text { Linear Sweep Voltammogram } \\ \text { MEA } & \text { Membrane Electrode Assembly } \\ \text { OCP } & \text { Open Circuit Potential } \\ \text { OPM } & \text { Oxford Performance Materials } \\ \text { PA } & \text { Phosphoric acid } \\ \text { PBI } & \text { Polybenzimidazole } \\ \text { PEK } & \text { Polyetherketone } \\ \text { PEEK } & \text { Polyetheretherketone } \\ \text { PEM } & \text { Proton Exchange Membrane and Polymer Electrolyte Membrane } \\ \text { PEMFC } & \text { Polymer Electrolyte Membrane Fuel Cell } \\ \text { PFSA } & \text { Perfluorinated Sulfonic Acid } \\ \text { PFSI } & \text { Perfluorosulfonimide } \\ \text { RT } & \text { Room Temperature, 25 }{ }^{\circ} \text { C } \\ \text { SDAPP } & \text { Sulfonated Diels-Alder Polyphenylenes } \\ \text { S-PFCB } & \text { sulfonated perfluorocyclobutyl aromatic ether } \\ \text { SDE } & \text { Sulfur Dioxide-depolarized Electrolyzer } \\ \text { SEM } & \text { Scanning Electron Microscopy } \\ \text { SHE } & \text { Standard Hydrogen Electrode } \\ \text { SNL } & \text { Sandia National Laboratory } \\ \text { SPEK } & \text { Sulfonated Polyetherketone } \\ \text { SPEKK } & \text { Sulfonated Polyetherketone-ketone } \\ \text { SRNL } & \text { Savannah River National Laboratory } \\ \text { SRS } & \text { Savannah River Site } \\ & \\ & \\ & \end{array}$




\subsection{EXECUTIVE SUMMARY}

This report summarizes results from all of the membrane testing completed to date at the Savannah River National Laboratory (SRNL) for the sulfur dioxide-depolarized electrolyzer (SDE). Several types of commercially-available membranes have been analyzed for ionic resistance and sulfur dioxide transport including perfluorinated sulfonic acid (PFSA), sulfonated polyether-ketone-ketone (SPEKK), and polybenzimidazole membranes (PBI). Of these membrane types, the poly-benzimidazole membrane, Celtec-L, exhibited the best combination of characteristics for use in an SDE. Several experimental membranes have also been analyzed including hydrated sulfonated Diels-Alder polyphenylenes (SDAPP) membranes from Sandia National Laboratory, perfluorosulfonimide (PFSI) and sulfonated perfluorocyclobutyl aromatic ether (S-PFCB) prepared by Clemson University, hydrated platinum-treated PFSA prepared by Giner Electrochemical Systems (GES) and Pt-Nafion ${ }^{\circledR}$ 115 composites prepared at SRNL.

The chemical stability, $\mathrm{SO}_{2}$ transport and ionic conductivity characteristics have been measured for several commercially available and experimental proton-conducting membranes. Commercially available PFSA membranes such as the Nafion ${ }^{\circledR}$ series exhibited excellent chemical stability and ionic conductivity in sulfur dioxide saturated sulfuric acid solutions. Sulfur dioxide transport in the Nafion ${ }^{\circledR}$ membranes varied proportionally with the thickness and equivalent weight of the membrane. Although the $\mathrm{SO}_{2}$ transport in the Nafion ${ }^{\circledR}$ membranes is higher than desired, the excellent chemical stability and conductivity makes this membrane the best commercially-available membrane at this time.

Initial results indicated that a modified Nafion ${ }^{\circledR}$ membrane incorporating Pt nanoparticles exhibited significantly reduced $\mathrm{SO}_{2}$ transport. Reduced $\mathrm{SO}_{2}$ transport was also measured with commercially available PBI membrane and several experimental membranes produced at SNL and Clemson. These membranes also exhibit good chemical stability and conductivity in concentrated sulfuric acid solutions and, thus, serve as promising candidates for the SDE. Therefore, we recommend further testing of these membranes including electrolyzer testing to determine if the reduced $\mathrm{SO}_{2}$ transport eliminates the formation of sulfur-containing films at the membrane/cathode interface.

$\mathrm{SO}_{2}$ transport measurements in the custom built characterization cell identified experimental limitations of the original design. During the last quarter of FY08 we redesigned and fabricated a new testing cell to overcome the previous limitations. This cell also offers the capability to test membranes under polarized conditions as well as test the performance of MEAs under selected electrolyzer conditions. 


\subsection{INTRODUCTION}

Hydrogen has been identified as a leading candidate to replace petroleum as part of the transition to a sustainable energy system, and major efforts are being conducted worldwide to develop the technologies and supporting activities required for this transition. In the United States, the federal research efforts are led by the U.S. Department of Energy (DOE). The U.S. DOE Hydrogen Program is an integrated inter-office program being conducted by the Office of Nuclear Energy (DOE-NE), Office of Energy Efficiency and Renewable Energy (DOE-EERE and Office of Fossil Energy and Office of Science. The primary objective of the DOE-NE Nuclear Hydrogen Initiative (NHI) is to develop the nuclear hydrogen production technologies necessary to produce hydrogen at a cost competitive with other alternative transportation fuels.

The focus of the NHI is on thermochemical cycles and high temperature electrolysis that can be powered by heat from high temperature gas reactors. The Hybrid Sulfur (HyS) Process is a variant of the sulfur-based thermochemical cycles[1], using a sulfur dioxide depolarized electrolyzer (SDE) to produce hydrogen, thus making it a thermo-electrochemical hybrid. Original work on the development of a SDE featured a parallel-plate electrolyzer with a separator or membrane to keep the anolyte and catholyte compartments separate [2].

Since this work was completed in the early 1980s, significant advances have occurred in electrolyzer technology principally in the area of hydrogen fuel cells. Advanced hydrogen fuel cells employ proton conductive membrane (PEM) with catalyst layers deposited on either side of the membrane, forming the respective anode and cathode of the electrochemical cell. The combination of membrane and electrode catalyst layers is referred to as the membrane electrode assembly or MEA. The Savannah River National Laboratory (SRNL) selected the fuel cell MEA electrolyzer design concept and successfully demonstrated the electrolyzer in 2005 [3].

There are many requirements of a PEM for the successful functioning of the electrolyzer. The PEM must be stable in highly corrosive solution (>30 wt $\% \mathrm{H}_{2} \mathrm{SO}_{4}$ saturated with $\mathrm{SO}_{2}$ ) and at high operating temperature $\left(>80^{\circ} \mathrm{C}\right)$, allow minimal transport of $\mathrm{SO}_{2}$, and must maintain high ionic conductivity under these conditions. Ideally, operating temperatures well above $80^{\circ} \mathrm{C}$ are desired with acid concentrations greater than $50 \mathrm{wt} \% \mathrm{H}_{2} \mathrm{SO}_{4}$. These requirements allow the electrolyzer to perform at high current density and low cell potential thus maximizing the energy efficiency for hydrogen production. Lastly the PEM serves to separate the anolyte reagents from the hydrogen output to prevent the production of undesired sulfur-based reaction products and poisoning of the cathode catalyst. This report focuses on evaluating commercially-available and experimental membranes for chemical stability, sulfur dioxide transport and ionic conductivity characteristics suitable for use in the sulfur dioxide-depolarized electrolyzer. 


\subsection{EXPERIMENTAL}

\subsection{SULFOR DIOXIDE AND SULFURIC ACID SOLUTIONS}

All tests used reagent grade sulfur dioxide gas (99.98\% purity) supplied by Scott Specialty Gases. Solutions of sulfuric acid were prepared at nominal concentrations of 30 or $50 \mathrm{wt} \%$ by gravimetrically diluting Certified ACS Plus sulfuric acid (assay 95 - 98 wt\%) supplied by Fisher Scientific with deionized, distilled water to a known volume. The concentration of the diluted sulfuric acid solution was determined by measuring the density and relating the density to concentration using data reported in reference [4]. The density of the diluted sulfuric acid solution was measured using an Anton-Paar DMA 4500 densitometer at $25{ }^{\circ} \mathrm{C}$. The measured concentrations, $29.2 \mathrm{wt} \%$ and $46.4 \mathrm{wt} \%$, were below the nominal gravimetric concentrations of 30 and $50 \mathrm{wt} \%$ respectively. For simplicity we have specified the nominal value as the concentration of the sulfuric acid solution used in tests reported in this document.

\subsection{MEMBRANE PREPARATION}

A list of the tested membranes is shown in Tables 1 and 2. During the selection process of commercially available and experimental membranes, an array of thicknesses, equivalent weights (EWs), chemistry, and reinforcements were considered. Preparation procedures of the membranes before testing were conducted according to the supplier's recommendations. Commercial membranes include perfluorinated sulfonic acid (PFSA) membranes and nonfluorinated membranes such as Fumatech sulfonated polyetherketone (SPEK), which were conditioned by washing in $0.5 \mathrm{M} \mathrm{H}_{2} \mathrm{SO}_{4}$ at $80^{\circ} \mathrm{C}$ for one hour and rinsing in deionized water (DI-water) at $80^{\circ} \mathrm{C}$ for another hour. Once treated, the membranes were stored in water until use. Commercial polybenzimidazole (PBI) type membranes from Celtec and sulfonated polyetherketone-ketone (SPEKK) from Oxford Performance Materials (OPM) were rinsed with water before use.

Table 1. Evaluated commercial membranes

\begin{tabular}{ccccc}
\hline \hline ID & Manufacturer & Classification & $\begin{array}{c}\text { Thickness } \\
(\boldsymbol{\mu m})\end{array}$ & $\begin{array}{c}\text { Equivalent Weight } \\
(\mathbf{g} / \mathbf{e q .})\end{array}$ \\
\hline Nafion $^{\circledR} 117$ & DuPont & PFSA & 180 & 1100 \\
\hline Nafion $^{\circledR} 112$ & DuPont & PFSA & 50 & 1100 \\
\hline F-1460 & Fumatech & PFSA & 60 & 1400 \\
\hline Celtec-V & PEMEAS & PBI with immobilize & 50 & ---- \\
\hline Celtec-L & PEMEAS & electrolyte & & ---- \\
\hline FKB & Fumatech & PEK & 50 & N/A \\
\hline OXPEKK & OPM & SPEK & 25 & 700 \\
\hline E-750 & Fumatech & SPEK & 50 & 50 \\
\hline \hline
\end{tabular}


Table 2 shows the experimental membranes prepared exclusively to reduce the transport of inert species such as dissolved $\mathrm{SO}_{2}$. The membranes include hydrated sulfonated Diels-Alder polyphenylenes (SDAPP) from Sandia National Laboratory, perfluorosulfonimide (PFSI) and sulfonated perfluorocyclobutyl aromatic ether (S-PFCB) prepared by Clemson University, hydrated platinum-treated PFSA prepared by Giner Electrochemical Systems (GES) and PtNafion ${ }^{\circledR} 115$ composites prepared at SRNL.

Table 2. Evaluated experimental membranes

\begin{tabular}{ccccc}
\hline \hline ID & Manufacturer & Classification & $\begin{array}{c}\text { Thickness } \\
(\boldsymbol{\mu m})\end{array}$ & $\begin{array}{c}\text { Equivalent Weight } \\
(\mathbf{g} / \mathbf{e q} .)\end{array}$ \\
\hline IQBAL 187 & Clemson & PFSI & 25 & 1318 \\
\hline SBVE TAS072 & Clemson & S-PFCB & 25 & N/A \\
\hline $\begin{array}{c}\text { Platinized } \\
\text { Nafion }{ }^{\circledR} 117\end{array}$ & GES & PFSA & 180 & 1100 \\
\hline SDAPP-2.2 & SNL & SDAPP & 50 & N/A \\
\hline SDAPP-1t & SNL & SDAPP & 50 & N/A \\
\hline SDAPP-4t & SNL & SDAPP & 25 & N/A \\
\hline SDAPP-1.6 & SNL & SDAPP & 76 & 1100 \\
\hline $\begin{array}{c}\text { Pt-Nafion } \\
{ }^{\circledR} 115\end{array}$ & SRNL & PFSA & 127 & \\
\hline \hline
\end{tabular}

\subsection{MEMBRANE CHARACTERIZATION}

Membrane $\mathrm{SO}_{2}$ transport was initially evaluated using a custom made permeation cell; a schematic of the cell is shown in Figure 1. The cell consists of two glass chambers joined by a Teflon ${ }^{\mathrm{TM}}$ bridge where the membrane is secured. The cell was filled with $30 \mathrm{wt} \%$ or 50 wt $\% \mathrm{H}_{2} \mathrm{SO}_{4}$ and purged with $\mathrm{N}_{2}$ or Ar. A three electrode system, which included a silversilver chloride reference electrode (Ag/AgCl, $196 \mathrm{mV}$ vs. standard hydrogen electrode (SHE)), a platinum flag as the counter electrode, and a platinum mesh as the working electrode, was used during measurements. The $\mathrm{SO}_{2}$ transport was monitored by measuring the current as a function of time while a constant potential is applied. A constant potential of $1040 \mathrm{mV}$ vs. SHE was applied on the working electrode while the current was measured as a function of time. $\mathrm{SO}_{2}$ permeating through the membrane was oxidized to sulfuric acid by the working electrode. A Bioanalytical Systems (BAS) B/W electrochemical analyzer was used to measure the current responses as a function of time. The membrane analyses discussed herein were developed from $\mathrm{SO}_{2}$ permeation data from using the above method. 


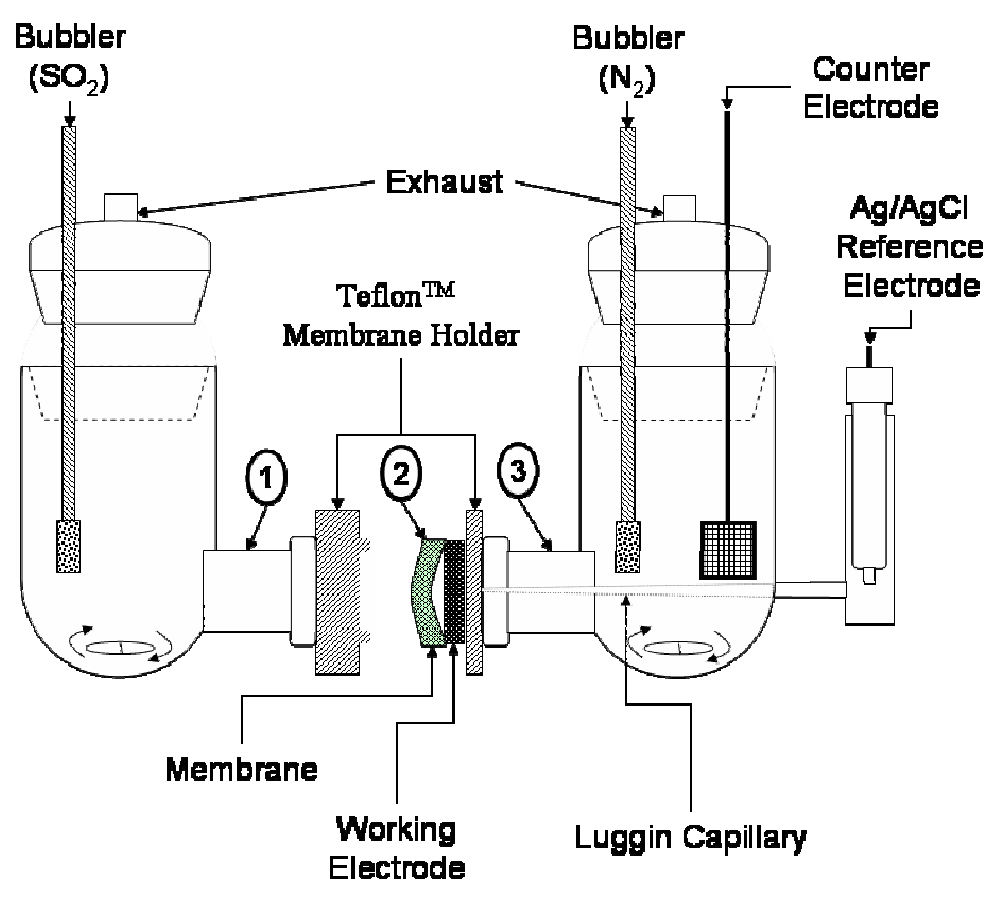

Figure 1. Simplified schematic of the original $\mathrm{SO}_{2}$ transport characterization cell.

At steady state conditions and assuming that all $\mathrm{SO}_{2}$ transported through the membrane is oxidized at the membrane surface, we can obtain the $\mathrm{SO}_{2}$ flux, $J_{\mathrm{SO}_{2}}$ from the electrical response using Faraday's Law,

$$
J_{\mathrm{SO}_{2}}=\frac{i}{n F}
$$

where ' $i$ ' is the current density in $\mathrm{A} / \mathrm{cm}^{2}$, ' $F$ ' is Faraday's constant (96,487 C/eq.), and ' $n$ ' is the number of electrons transferred. The measured flux can then be used to calculate the transport coefficient using the modified Fick's Law of diffusion (equation 2).

$$
J_{S_{2}}=\frac{D C_{0}}{L}
$$

where the thickness, ' $L$ ', of the membrane, the transport coefficient, ' $D$ ', and the bulk concentration, 'Co'.

Over the course of testing, we identified three limitations of the original characterization cell design. These limitations are described below. 


\section{Limitation \#1}

During testing, the sulfuric acid solution on the left chamber must be saturated with $\mathrm{SO}_{2}$. While this is easily achieved by bubbling and stirring an excess of $\mathrm{SO}_{2}$ in the solution, once $\mathrm{SO}_{2}$ starts to diffuse through the membrane and is consumed in the right chamber, a concentration gradient is formed at the membrane interface. The change in concentration, ' $C_{o}$ ', causes a false low measurement in transport. To correct for this measurement flaw, acid saturated with $\mathrm{SO}_{2}$ must be forced to the membrane.

\section{Limitation \#2}

Most of the tested membranes are hygroscopic and will swell or shrink depending on the humidity and temperature of exposure. The magnitude of the change is due to the characteristics of the polymer system. In addition, during cell assembly the membrane sample can have small wrinkles which can be problematic to install straight. These factors will change the surface area exposed to $\mathrm{SO}_{2}$, and more critically, will affect the distance from the working electrode. This cannot be corrected for in the original $\mathrm{SO}_{2}$ transport characterization cell resulting in an unknown membrane to working electrode distance, and the assumed sample thickness, ' $L$ ', entered in the transport formula will be incorrect. To correct for this flaw in the measurement, the membrane must be pressed flat on to the working electrode, without disturbing the area exposed to $\mathrm{SO}_{2}$.

\section{Limitation \#3}

When $\mathrm{SO}_{2}$ reaches the working electrode, it is combined with water and electrochemically oxidized to sulfuric acid. This process will cause the water concentration to decrease and the sulfuric acid concentration to increase at the surface interface between the membrane sample and the working electrode. Many membranes containing water channels like Nafion ${ }^{\circledR}$ will dehydrate as a result increased sulfuric acid concentration. The membrane pores will shrink, lowering the $\mathrm{SO}_{2}$ flux as a result. To correct for this measurement flaw, fresh acid must be forced to the membrane in order to maintain the acid concentration at the desired value. This problem area is not taken into account directly by the equation used for transport, but is believed to increase the uncertainty of the final measurement.

In order to correct the limitations described above, a new testing cell was designed and fabricated in last quarter of FY08. Figure 2 shows a simplified schematic of the modified $\mathrm{SO}_{2}$ transport characterization cell. This design incorporates a diffusion layer in the left chamber where acid saturated with $\mathrm{SO}_{2}$ is forced by pump A into the membrane acid interface. Additionally, the diffusion layer presses the membrane to the working electrode eliminating or minimizing limitations 1 and 2. A perforated tantalum support was machined in order to provide an electrical connection to the working electrode. Finally, in order to eliminate limitation \#3, a diffusion media/counter-reference electrode was incorporated in the right chamber to allow pump B to supply the membrane with fresh acid.

In addition to improved $\mathrm{SO}_{2}$ transport characteristics under rest conditions, this cell will allow measurements under polarized conditions. Furthermore, this cell allows testing of MEA performance under electrolyzer conditions using samples that are much smaller than that used in the single cell electrolyzer. 


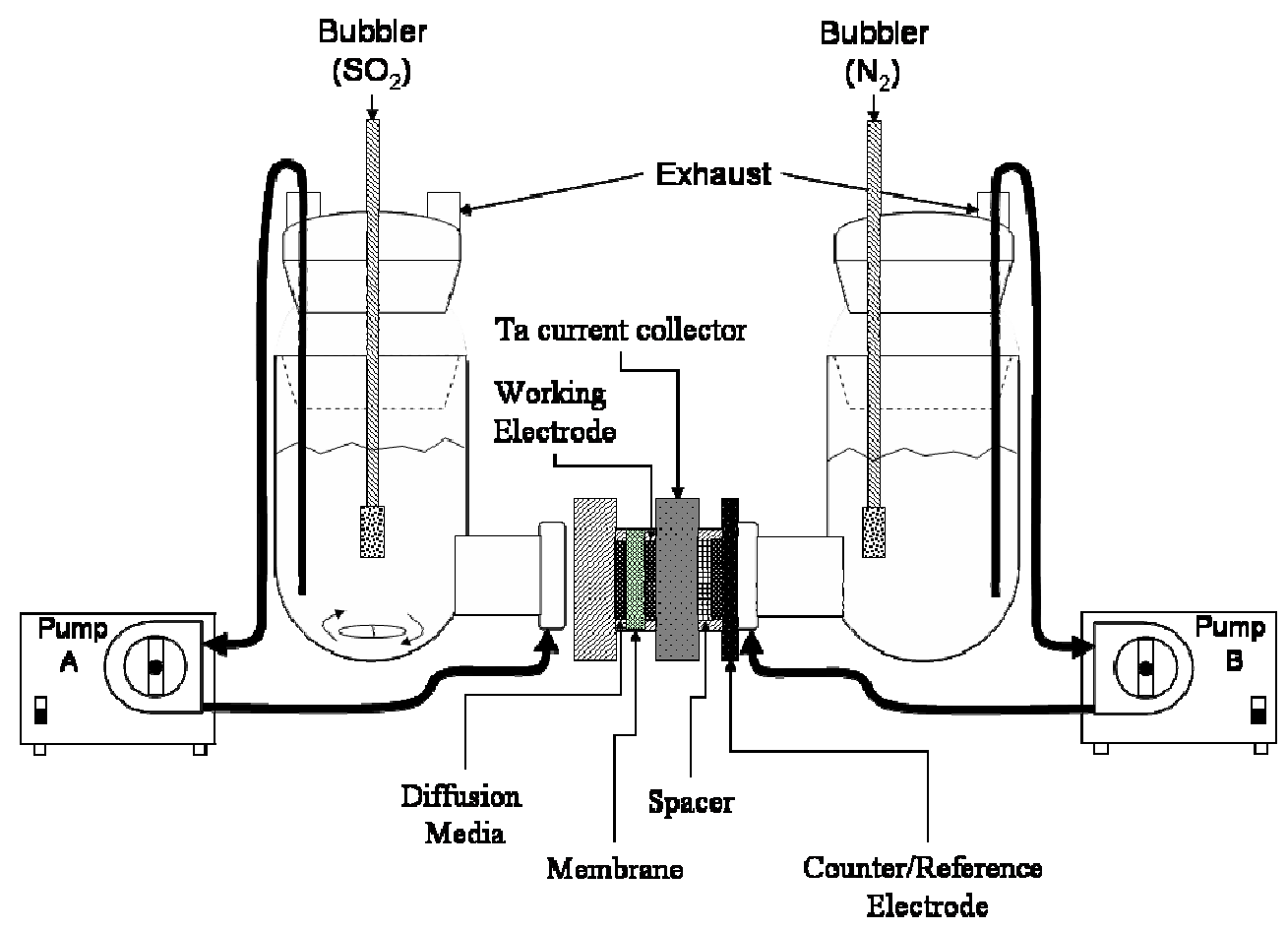

Figure 2. Simplified schematic of the modified $\mathrm{SO}_{2}$ transport characterization cell. 
The Electrochemical Impedance Spectroscopy (EIS) technique was used to evaluate the ionic resistivity $(\rho)$ as a function of acid concentration. For this measurement an ionic conductivity cell was used. Figure 3 shows a simplified schematic of the cell. A two electrode system was used for the measurement. After allowing several minutes for the membrane to equilibrate, a $10 \mathrm{mV}$ vs. OCP (open circuit potential) sinusoidal voltage was imposed across the membrane at frequencies between $500 \mathrm{kHz}$ and $200 \mathrm{~Hz}$. The resulting response was displayed in the form of Nyquist plots. The resistance was calculated from the value of the real impedance when the imaginary response is zero. The resistivity was calculated using equation 3.

$$
\rho=\frac{Z_{\text {real }} A}{L}
$$

where ' $L$ ' is the thickness of the membrane, ' $A$ ' is the area available for proton conduction, and ' $Z_{\text {real }}$ ' is the real part of the impedance response when the imaginary impedance is zero. A PARSTAT 2273 potentiostat/frequency analyzer from Princeton Applied Research was used for this measurement.

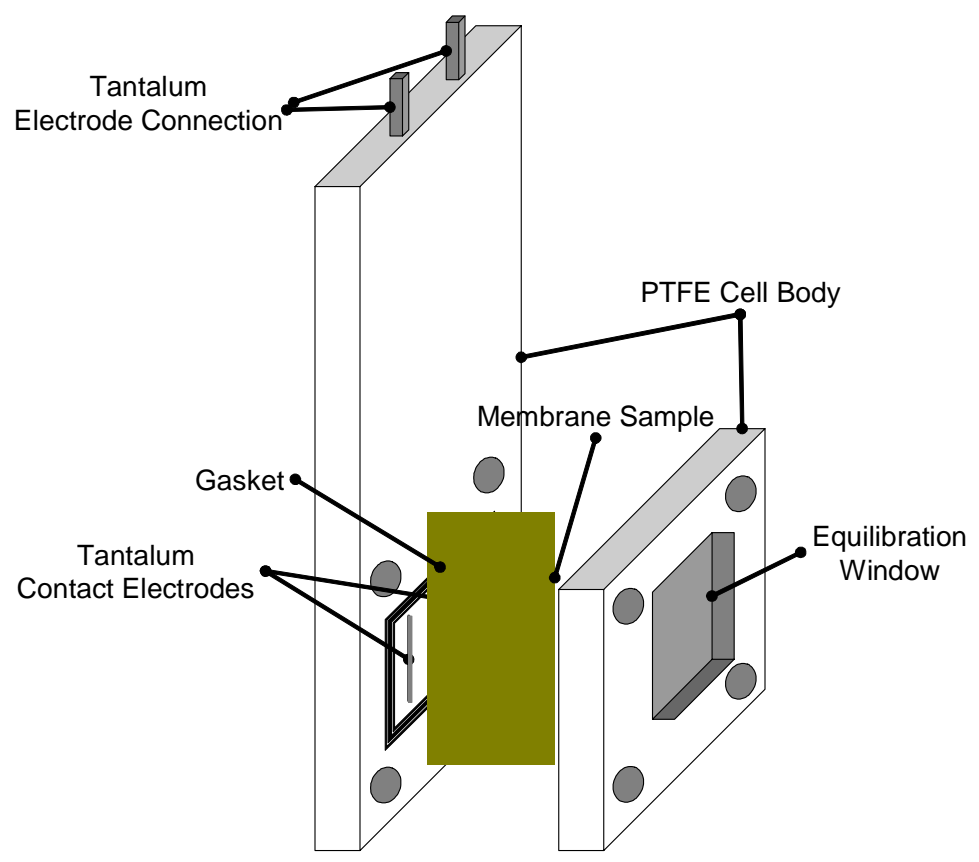

Figure 3. Simplified schematic of the ionic conductivity characterization cell. 


\subsection{RESULTS AND DISCUSSION}

\subsection{SULFUR DIOXIDE TRANSPORT AT REST CONDITIONS}

In a perfectly efficient SDE, all of the $\mathrm{SO}_{2}$ is oxidized to sulfuric acid. In practice, the cell is not $100 \%$ efficient and some of the $\mathrm{SO}_{2}$ migrates from the anolyte side through the membrane into the catholyte side of the cell. Migration of the neutral species, $\mathrm{SO}_{2}$, largely arises by diffusion driven by the concentration gradient from the anolyte to the catholyte. Upon reaching the cathode, $\mathrm{SO}_{2}$ can be reduced to produce sulfur and sulfides. Reduction of the $\mathrm{SO}_{2}$ decreases the electrical efficiency of the cell. The $\mathrm{SO}_{2}$ transport to the cathode not only affects the purity of the hydrogen being produced, but the long term effects of these impurities incorporated in the membrane, cathode catalyst, or diffusion layer are not yet known.

Thus, a separator with high ionic conductivity, minimal $\mathrm{SO}_{2}$ transport, and long term stability is needed. The current design for the SDE is based on a polymer electrolyte membrane fuel cell (PEMFC). The Nafion ${ }^{\circledR}$ family of perfluorinated sulfonic acid membranes is an attractive candidate membrane due to its relatively high ionic conductivity and chemical stability in strong acid solutions. However, previous testing indicated fairly high $\mathrm{SO}_{2}$ transport across this membrane to the cathode.

A review of the literature revealed a number of commercially available membranes that may be suitable for use in the SDE. Table 1 provides the list of commercial membranes that were selected for testing $\mathrm{SO}_{2}$ transport. The first group of membranes selected was the PFSA family, which have been developed for PEM fuel cells for operation at low temperatures $\left(80^{\circ} \mathrm{C}\right)$. The properties of the PFSA type membrane with an equivalent weight (EW) of 1100 is considered in this work as the baseline to which all other membranes were compared.

Membranes developed for Direct Methanol (DM) fuel cells such as SPEKK and SPEK are studied in this work due to their improved properties to reduce the crossover of methanol and their ability to operate at higher temperatures (up to $140^{\circ} \mathrm{C}$ ). Finally membranes originally developed for Phosphoric Acid (PA) fuel cells from the PBI family were selected for their ability to operate at temperatures up to $200{ }^{\circ} \mathrm{C}$ under dry conditions. Unlike the sulfonated type of membranes (PFSA, SPEKK or SPEK) that employ sulfonic acid groups to transport hydrated protons, these PBI membranes employ a hopping mechanism in which immobilized anions (such as PA) act as proton solvents and provide a path for rapid proton exchange. As a result, protons are conducted without the creation of water channels that transport water and other inert molecules.

Table 2 provides the list of experimental membranes that are being develop to decrease the transport of neutral species such as $\mathrm{SO}_{2}$. The first membrane consists of the use of platinum nano-particles embedded in the pores of a Nafion ${ }^{\circledR} 117$ membrane. A similar approach has been considered for the development of methanol-blocking membranes without adverse effects on the proton conductivity [4]. The other membrane consisted of several samples of the SDAPP class of materials, which provides good proton conductivity with reduced water transport. 
The permeation rate of $\mathrm{SO}_{2}$ species through the membranes was monitored by an electrochemical technique (see experimental section). The flux profile contains three distinct regions. Initially, the currents are flat indicating that the system is building up $\mathrm{SO}_{2}$ concentration in the chamber and membrane. As $\mathrm{SO}_{2}$ passes through the membrane, it is oxidized by the working electrode resulting in a measurable permeation. The permeation current increases with time until steady-state conditions (i.e., third region) are reached and no change in the flux is observed.

The effect of the acid concentration on the $\mathrm{SO}_{2}$ flux through the commercial membrane samples is displayed in Figure 4. At low acid concentration, the $\mathrm{SO}_{2}$ transport is highest (see Figure 4a) and decreases when the acid concentration is increased from $30 \mathrm{wt} \%$ to $50 \mathrm{wt} \%$ (see Figure 4b). This behavior can be explained by the change in water concentration on the polymer matrix.

At low acid concentrations the membrane hydration level is higher, as a result the polymer swells increasing the polymer pore diameter. As the acid concentration increases, the hydration level of the polymer decreases causing the polymer matrix and the pores to shrink. The shrinkage of the pores results in smaller channels that reduce the amount of inert species permeating through the water channels. Although beneficial in reducing the $\mathrm{SO}_{2}$ transport, the decrease in water also affects the proton transport resulting in an increase in ionic resistivity (i.e., decrease in ionic conductivity). Such decreases in ionic conductivity as a function of acid concentration have been observed by Junginger et al. [5].

The dependence of membrane thickness on $\mathrm{SO}_{2}$ transport with the same polymer chemistry can be observed in Figure 4a by comparing the fluxes for Nafion ${ }^{\circledR} 112$ (50 microns) and Nafion ${ }^{\circledR} 117$ (180 microns). As expected, the thinner Nafion ${ }^{\circledR} 112$ membrane exhibited a higher $\mathrm{SO}_{2}$ flux than that of the thicker Nafion ${ }^{\circledR} 117$ membrane. The $\mathrm{SO}_{2}$ transport measured for the Nafion ${ }^{\circledR} 112$ membrane measured 3.1 times higher than that of the Nafion ${ }^{\circledR} 117$ membrane, which is very similar to the difference in thickness between the two membranes (i.e., Nafion ${ }^{\circledR} 117$ membrane is 3.5 times thicker than the Nafion ${ }^{\circledR} 112$ membrane.

The concentration of sulfonic acid groups (i.e., equivalent weight) in the membrane also affects the transport of $\mathrm{SO}_{2}$. As observed above, when the membranes hydrate, especially PFSA polymers, water binds to the ionic groups to produce a fully separate phase with concentrated ionic domains. This domain contains channels where neutral species that dissolve in water can diffuse. As a consequence, a membrane with the same thickness but higher EW will transport less $\mathrm{SO}_{2}$ than a material with lower $\mathrm{EW}$ as the number of domains is decreased in the membrane with higher EW.

The effect of the amount of conductive groups on the flux can be observed by comparing Nafion ${ }^{\circledR} 112$ and 117 membranes (EW= $\left.1100 \mathrm{~g} / \mathrm{eq}\right)$ and that of the F-1460 (1400 g/eq) membrane. The $\mathrm{SO}_{2}$ transport for F-1460 is significantly lower than that of the Nafion ${ }^{\circledR} 112$ membrane. After accounting for the slightly greater thickness (60 versus 50 microns), the higher EW F-1460 membrane exhibits much lower $\mathrm{SO}_{2}$ transport than the Nafion ${ }^{\circledR} 112$ membrane. Compared to the Nafion ${ }^{\circledR} 117$ membrane which is 3 times thicker than the F1460 membrane, the $\mathrm{SO}_{2}$ transport for the F-1460 membrane is about 1.4 times higher than 
that of the Nafion ${ }^{\circledR} 117$ membrane. This flux is approximately 2 times lower, which is attributed to the difference in membrane thickness.

The backbone of the polymer also affects its properties. For example, polymers form the SPEK family such as E-750, which have an EW of 700 have a much lower $\mathrm{SO}_{2}$ transport than a membrane from the PFSA family with a higher EW (such as Nafion ${ }^{\circledR} 112$ ). The main possible reason for the reduction of $\mathrm{SO}_{2}$ flux is the use of polymers with stiffer backbones that will prevent the phase separation and the formation of ionic acid domains [6]. Among the membranes tested, OXPEKK showed the lowest flux followed closely by the FKB and Celtec-L membranes.

The effects of the acid concentration, membrane thickness, and temperature on the $\mathrm{SO}_{2}$ flux through Nafion ${ }^{\circledR}$ membrane samples are observed in Figure 5. At low temperature the $\mathrm{SO}_{2}$ transport is highest and it decreases as the temperature is increased (see Figure 5a). A similar behavior is observed when the acid concentration is increased from $30 \mathrm{wt} \%$ to 50 wt\% (see Figure 5b).

At high temperatures the transport is expected to increase since the transport coefficient is dependent on temperature. However, the permeation cell is not pressurized and the solubility of $\mathrm{SO}_{2}$ in the acid solution decreases as the temperature is increased. In $30 \mathrm{wt} \%$ acid, the concentration of $\mathrm{SO}_{2}$ decreases from $1.090 \mathrm{M}$ at $25{ }^{\circ} \mathrm{C}$ to $0.4260 \mathrm{M}$ and $0.2122 \mathrm{M}$ at $50{ }^{\circ} \mathrm{C}$ and $70{ }^{\circ} \mathrm{C}$, respectively. A similar behavior is observed for the samples in $50 \mathrm{wt} \%$ acid solution with the exception of Nafion ${ }^{\circledR} 117$ where an anomaly is observed at $25^{\circ} \mathrm{C}$. According to the previous data, the membrane tested at $25^{\circ} \mathrm{C}$ should have a $\mathrm{SO}_{2}$ transport higher than the sample tested at $50{ }^{\circ} \mathrm{C}$, but the recorded transport shows the opposite. This result will be repeated to corroborate the presented result. 

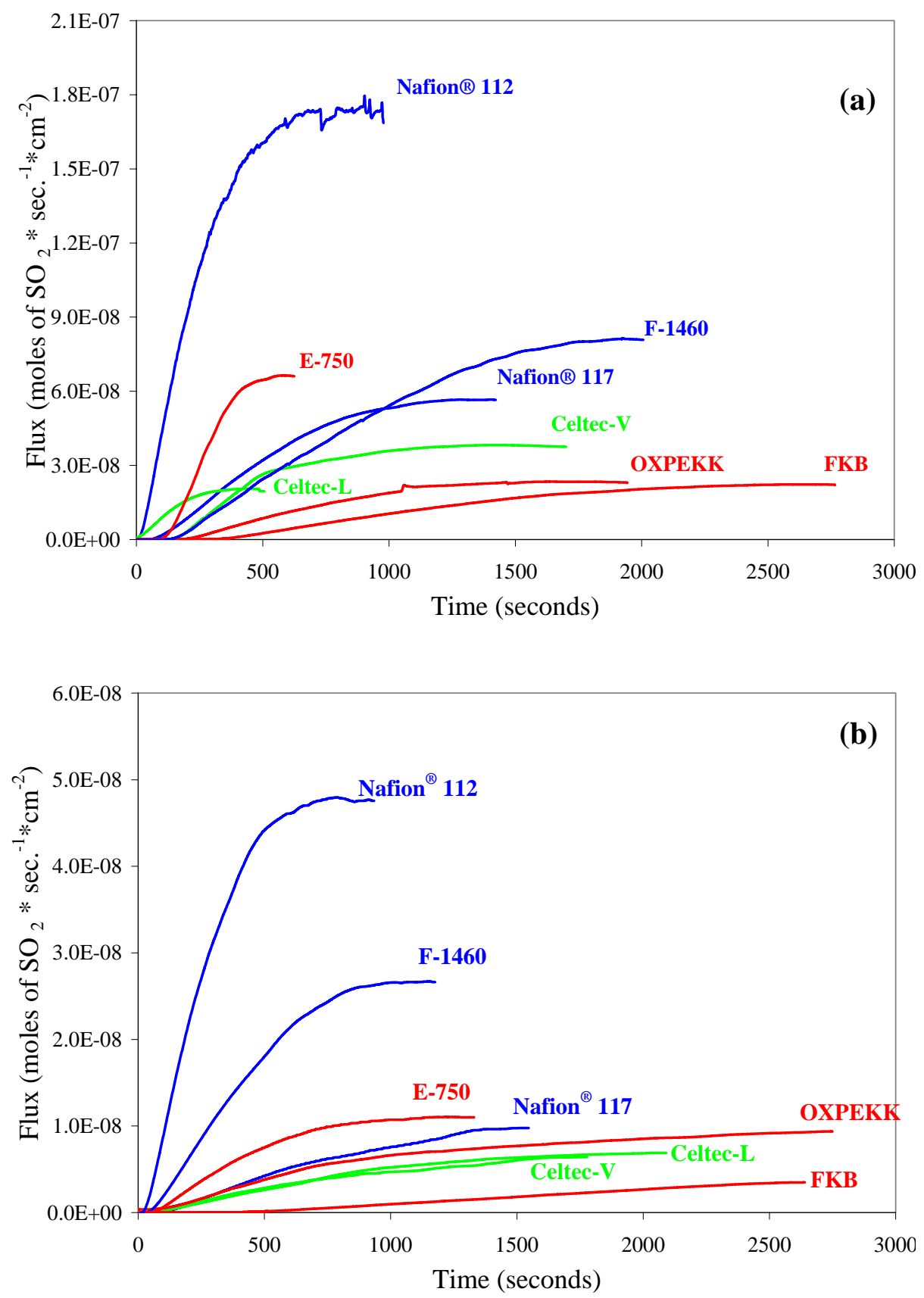

Figure 4. $\mathrm{SO}_{2}$ transport through commercial membranes immersed in (a) $30 \mathrm{wt} \%$ and (b) 50 wt\% $\mathrm{H}_{2} \mathrm{SO}_{4}$ saturated with $\mathrm{SO}_{2}$ at room temperature. Working electrode set at $1040 \mathrm{mV}$ vs. SHE 

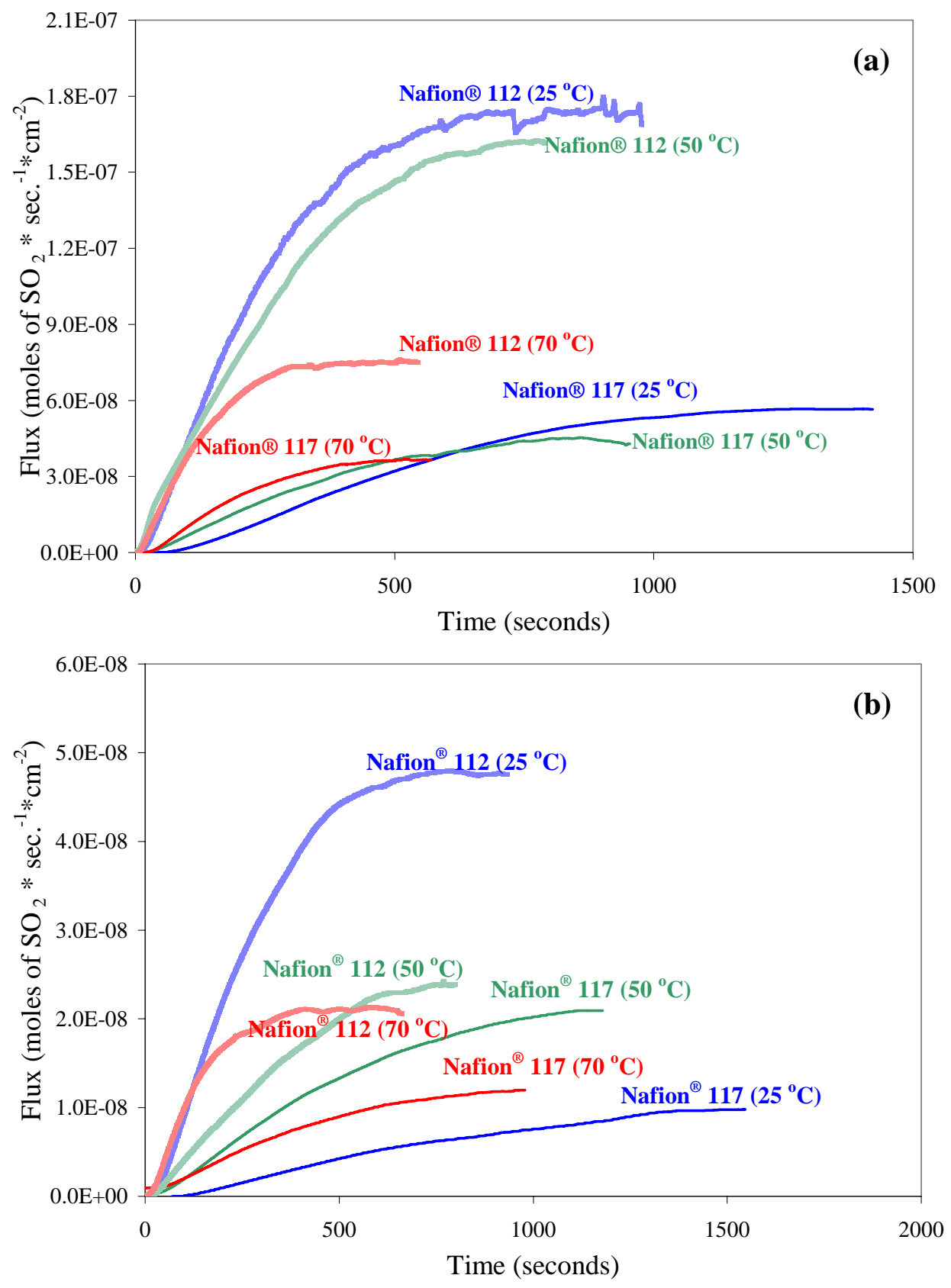

Figure 5. $\mathrm{SO}_{2}$ transport through commercial membranes immersed in (a) $30 \mathrm{wt} \%$ and (b) $50 \mathrm{wt} \% \mathrm{H}_{2} \mathrm{SO}_{4}$ saturated with $\mathrm{SO}_{2}$ at different temperatures. Working electrode set at $1040 \mathrm{mV}$ vs. SHE.

The need for improved PEM performance and operating lifetime in hydrogen and methanol fuel cells has seen considerable effort to develop new conductive polymer systems and to modify commercial membranes to increase conductivity, chemical stability and neutral molecule crossover (e.g., methanol). From a review of the literature we identified several 
commercial membranes that appeared as promising candidates for the SDE. These included polybenzimidazole (PBI), polyetheretherketone (PEEK) and sulfonated polyetheretherketone (SPEEK). In addition we identified several experimental membranes, the sulfonated Diels Alder polyphenylene class of membranes (SDAPP) being developed at Sandia National Laboratories, the sulfonated perfluorinated cyclobutyl (S-PFCB) class of membranes and the perfluorosulfonimide (PFSI) class of membranes, both of which are being developed at Clemson University.

We also identified several experimental modified PFSA membranes for evaluation. These included Nafion ${ }^{\circledR}$ modified by incorporating platinum nano-particles produced by Giner Electrochemical Systems (GES) and SRNL and hybrid PFSA membranes produced by Case Western Reserve University researchers. The latter hybrid membranes feature a barrier layer either on one side or sandwiched between two layers of the Nafion ${ }^{\circledR}$ membrane.

Figures 6 - 8 present plots of the $\mathrm{SO}_{2}$ flux measured for the experimental membranes tested to date. Table 3 provides a summary of the measured $\mathrm{SO}_{2}$ flux rates. As can be observed from the figures, incorporating Pt into the pores of the membrane, we are able to slow the transport of $\mathrm{SO}_{2}$ while keeping the ionic conductivity high. The next step is to incorporate controlled amounts of Pt inside the pores of the membrane in order to increase the selectivity of the membranes. The Pt-treated PFSA from Giner Electrochemical Systems is shown as a comparison.

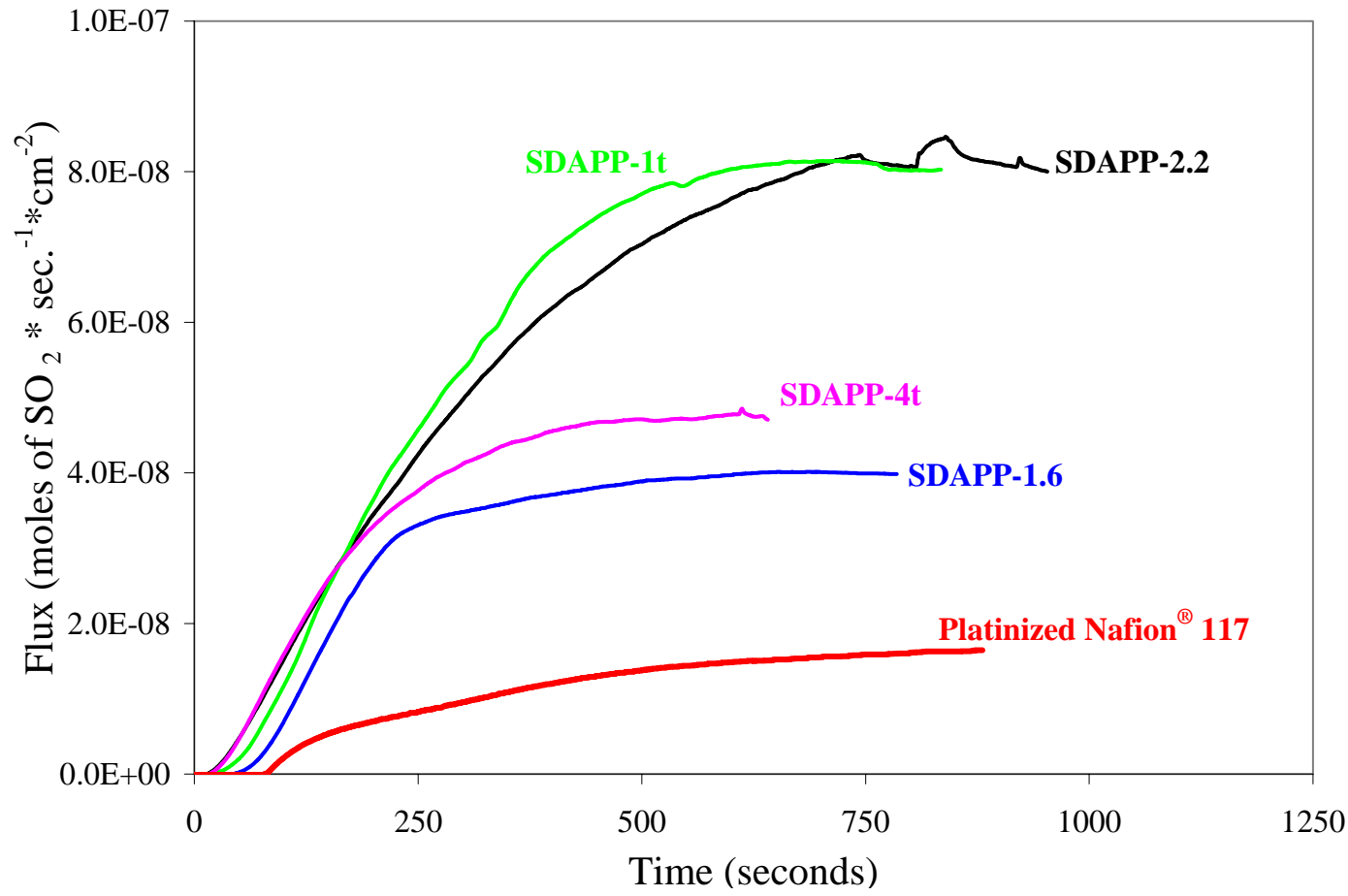

Figure 6. $\mathrm{SO}_{2}$ transport through experimental membranes immersed in $30 \mathrm{wt} \% \mathrm{H}_{2} \mathrm{SO}_{4}$ saturated with $\mathrm{SO}_{2}$ at room temperature. Working electrode set at $1040 \mathrm{mV}$ vs. SHE 


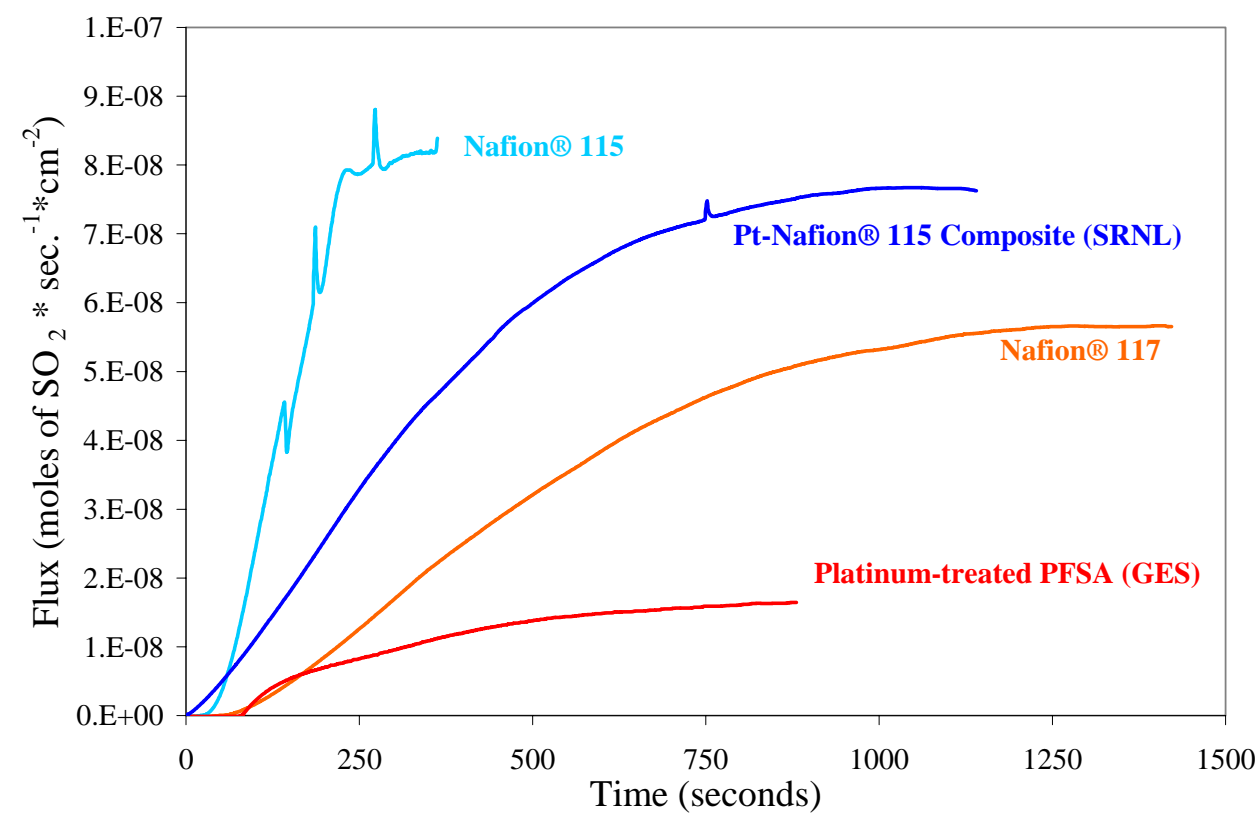

Figure 7. $\mathrm{SO}_{2}$ transport through PFSA experimental membranes immersed in $30 \mathrm{wt} \%$ $\mathrm{H}_{2} \mathrm{SO}_{4}$ saturated with $\mathrm{SO}_{2}$ at room temperature. Working electrode set at $1040 \mathrm{mV}$ vs. SHE.

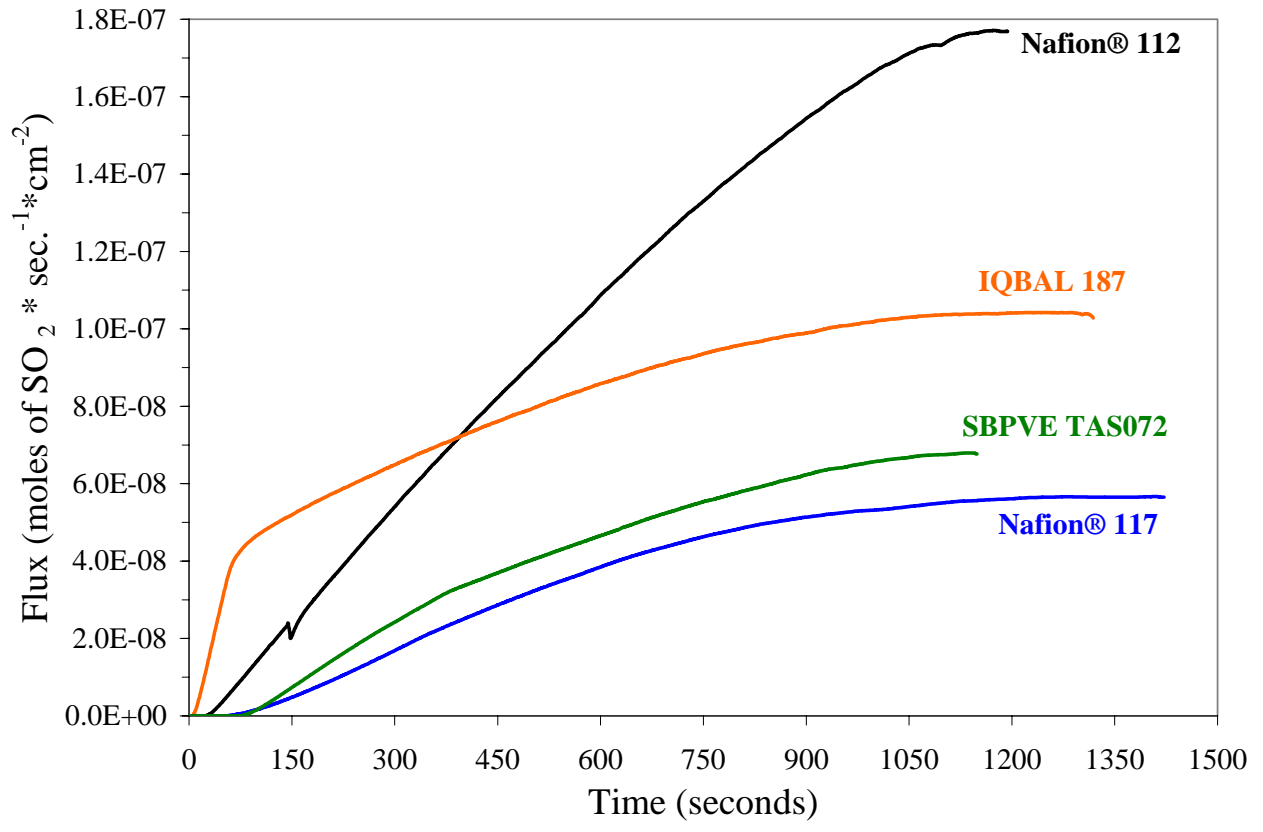

Figure 8. $\mathrm{SO}_{2}$ transport through non-PFSA experimental membranes immersed in $30 \mathrm{wt} \% \mathrm{H}_{2} \mathrm{SO}_{4}$ saturated with $\mathrm{SO}_{2}$ at room temperature. Working electrode set at $1040 \mathrm{mV}$ vs. SHE. 
Table 3 shows the $\mathrm{SO}_{2}$ transport coefficient for all of the membranes tested to date. The commercial membranes were tested at two different acid concentrations, 30 and $50 \mathrm{wt} \%$ $\mathrm{H}_{2} \mathrm{SO}_{4}$. By increasing the sulfuric acid concentration the transport coefficient was reduced by a factor of between 2 and 5 . The new experimental membranes showed a decrease in the $\mathrm{SO}_{2}$ transport coefficients, with the SDAPP membrane samples showing similar values to those of the PBI membranes. The platinized Nafion ${ }^{\circledR} 117$ membrane showed a reduction by a factor of three compared to that of the un-modified Nafion ${ }^{\circledR} 117$ membrane. The overall performance of the experimental membranes in comparison to PFSA membranes shows promising results for the reduction of $\mathrm{SO}_{2}$ transport through ion-conducting membranes.

Table 3: $\mathrm{SO}_{2}$ transport coefficient through the tested membranes immersed in $30 \mathrm{wt} \%$ and 50 wt\% $\mathrm{H}_{2} \mathrm{SO}_{4}$ saturated with $\mathrm{SO}_{2}$ at room temperature. Working electrode set at $1040 \mathrm{mV}$ vs. SHE.

\begin{tabular}{|c|c|c|}
\hline \multirow[b]{2}{*}{ Membrane } & \multicolumn{2}{|c|}{ Transport Coefficient $\left(\mathrm{cm}^{2} / \mathrm{s}\right)$} \\
\hline & 30 wt. $\% \mathrm{H}_{2} \mathrm{SO}_{4}$ & 50 wt. $\% \mathrm{H}_{2} \mathrm{SO}_{4}$ \\
\hline Nafion $^{\circledR} 117$ (EW 1100) & 9.33E-7 & 9.33E-7 \\
\hline F-1460 & 4.45E-7 & 1.67E-7 \\
\hline Celtec-V & $6.76 \mathrm{E}-7$ & $3.44 \mathrm{E}-7$ \\
\hline Celtec-L & $7.24 \mathrm{E}-7$ & $2.30 \mathrm{E}-8$ \\
\hline OXPEKK & $5.28 \mathrm{E}-8$ & $2.46 \mathrm{E}-8$ \\
\hline FKB & $1.61 \mathrm{E}-7$ & 2.94E-8 \\
\hline E-750 & $3.03 \mathrm{E}-7$ & 5.77E-8 \\
\hline SDAPP-2.2 & $3.85 \mathrm{E}-7$ & ----- \\
\hline SDAPP-1t & $3.68 \mathrm{E}-7$ & ----- \\
\hline SDAPP-4t & $1.11 \mathrm{E}-7$ & ----- \\
\hline SDAPP-1.6 & $2.79 \mathrm{E}-7$ & ----- \\
\hline $\begin{array}{c}\text { Platinized } \\
\text { Nafion }^{\circledR} 117\end{array}$ & $2.71 \mathrm{E}-7$ & ----- \\
\hline
\end{tabular}

\subsection{SULFUR DIOXIDE TRANSPORT UNDER APPLIED POTENTIAL}

During normal electrolyzer operation water is dragged along with the protons across the membrane by what is termed electro-osmotic drag. Uncharged molecules dissolved in water are also subject to electro-osmotic drag. In an attempt to quantify the effect of proton transport through the membrane on the $\mathrm{SO}_{2}$ transport, the permeation cell was modified in order to accommodate a two electrode configuration. During the experiment, $\mathrm{SO}_{2}$ transport initially occurs by diffusion in the absence of polarization. Once the oxidation current reaches steady state due to diffusion, the cell was polarized passing a current of $0.2 \mathrm{~A}$. 
Figure 9 shows the typical behavior of $\mathrm{SO}_{2}$ transport observed when an applied current is set across the membrane immersed in $30 \mathrm{wt} \% \mathrm{H}_{2} \mathrm{SO}_{4}$ saturated with $\mathrm{SO}_{2}$ at room temperature. The initial response of the system is an almost instantaneous increase in the $\mathrm{SO}_{2}$ flux. After the initial spike, the current starts to decline. This would be expected since the applied current is in fact consuming most of the $\mathrm{SO}_{2}$ dissolved in solution and, therefore, reducing the $\mathrm{SO}_{2}$ concentration on the bulk solution available for transport across the membrane. After several minutes, the current is discontinued (i.e., the cell is depolarized) and the system is allowed to relax until it reaches steady state conditions again. After a few more minutes, the second set of electrodes were disconnected from the potentiostat.

From the initial spike in current it appears that polarization does affect the $\mathrm{SO}_{2}$ transport. However the observed spike may be a response of the primary potentiostat with the second electrode system. Thus, we cannot quantify the effect of polarization on $\mathrm{SO}_{2}$ transport at this time. We plan to investigate the effect of polarization in FY09 with the newly fabricated transport characterization cell (see Section 3.3, Figure 2).

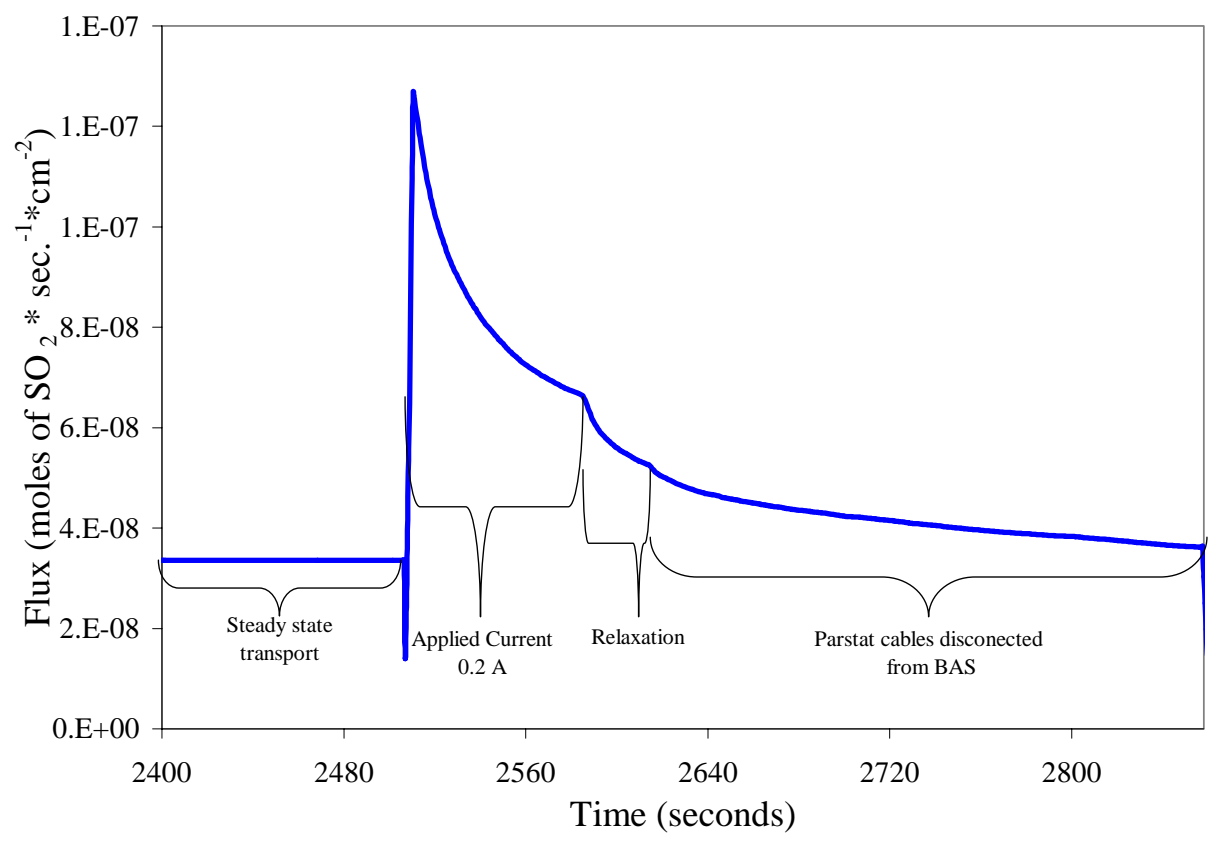

Figure 9. Typical behavior representing the effect of an applied current across the membrane on the $\mathrm{SO}_{2}$ transport through a cationic membrane immersed in $30 \mathrm{wt} \% \mathrm{H}_{2} \mathrm{SO}_{4}$ saturated with $\mathrm{SO}_{2}$ at room temperature. Working electrode set at $1040 \mathrm{mV}$ vs. SHE.

\subsection{IN-PLANE IONIC CONDUCTIVITY}

Through-plane conductivity is the measurement of interest in an operating electrolyzer. However, in order to obtain a good through-plane conductivity measurement, the membrane must be assembled in a membrane electrode assembly (MEA). Determination of the in-plane conductivity is simpler than the through-plane conductivity and does not require the preparation of a MEA. A drawback of the in-plane measurement is that in some cases the in- 
plane conductivity measurement can differ from the through plane due to surface conduction. This occurs when the liquid electrolyte (i.e., sulfuric acid) exhibits a better conductivity than the solid electrolyte (i.e., membrane). However, the ease of the in-plane measurement makes it a good qualitative tool to screen different membrane types for ionic conductivity.

In order to produce hydrogen efficiently, the SDE requires a membrane with high proton conductivity to minimize IR losses across the cell. The in-plane ionic resistance was calculated from [eq1] and plotted in Figure 10 in terms of proton conductivity for each membrane as a function of acid concentration and temperature. As seen in the plots, the conductivity is directly proportional to temperature. Also, we observed an increase in the conductivity when the membrane is contacted with $30 \mathrm{wt} \%$ sulfuric acid compared to that in water. In general, samples with a high degree of sulfonation (e.g., SDAPP-2.2, OXPEKK, Platinized Nafion ${ }^{\circledR} 117$ (PN117) and Nafion ${ }^{\circledR} 112$ ) exhibited very high conductivity. Note that the SPEK membrane from Fumatech, E-750, showed good conductivity in water, however it quickly degraded when exposed to high sulfuric acid concentrations.

Consequently, the SPEK membrane is not a good candidate for the SDE.

Table 4. $\mathrm{SO}_{2}$ transport coefficient conductivity and selectivity of experimental membranes tested at room temperature conditions.

\begin{tabular}{|c|c|c|c|}
\hline Membrane & $\begin{array}{c}\mathrm{SO}_{2} \text { Transport } \\
\text { Coefficient }\left(\mathrm{cm}^{2} / \mathrm{s}\right) \\
\text { in } 30 \text { wt. } \% \mathrm{H}_{2} \mathrm{SO}_{4}\end{array}$ & $\begin{array}{c}\text { Conductivity }(\mathrm{S} / \mathrm{cm}) \text { in } \\
\text { Water }\end{array}$ & $\begin{array}{l}\text { Selectivity } \\
\left(\mathrm{S}^{*} \mathrm{~s}^{*} \mathrm{~cm}^{-3}\right)\end{array}$ \\
\hline Nafion $®(E W ~ 1100)$ & $9.33 \times 10^{-7}$ & $1.22 \times 10^{-1}$ & $1.30 \times 10^{5}$ \\
\hline $\begin{array}{c}\text { Pt-Nafion } \AA 115 \\
\text { composite }\end{array}$ & $8.92 \times 10^{-7}$ & $1.35 \times 10^{-1}$ & $1.52 \times 10^{5}$ \\
\hline $\begin{array}{c}\text { Platinum treated } \\
\text { PFSA }\end{array}$ & $2.71 \times 10^{-7}$ & $1.37 \times 10^{-1}$ & $5.03 \times 10^{5}$ \\
\hline IQBAL 187 & $2.42 \times 10^{-7}$ & -------- & ------- \\
\hline SBPVE TAS072 & $1.56 \times 10^{-7}$ & ------- & ------- \\
\hline
\end{tabular}

Table 4 shows the transport coefficient, conductivity and selectivity for selected experimental membranes. These membranes were tested at $30 \mathrm{wt} \% \mathrm{H}_{2} \mathrm{SO}_{4}$ at room temperature. The new experimental membranes from Clemson University showed significant decrease in the transport coefficient, were the Pt-Nafion ${ }^{\circledR} 115$ composite shows a slight decrease to the unmodified Nafion ${ }^{\circledR}$. The conductivity of the Nafion ${ }^{\circledR}$ composite from SRNL showed an increase in conductivity, making the overall selectivity higher. We believe that by increasing the Pt position inside the membrane and the quantity we will be able to further improve the selectivity. We were unable to perform the conductivity test on the Clemson samples received to date due to the small sample size. These measurements will be completed in FY09 upon receipt of new samples. 

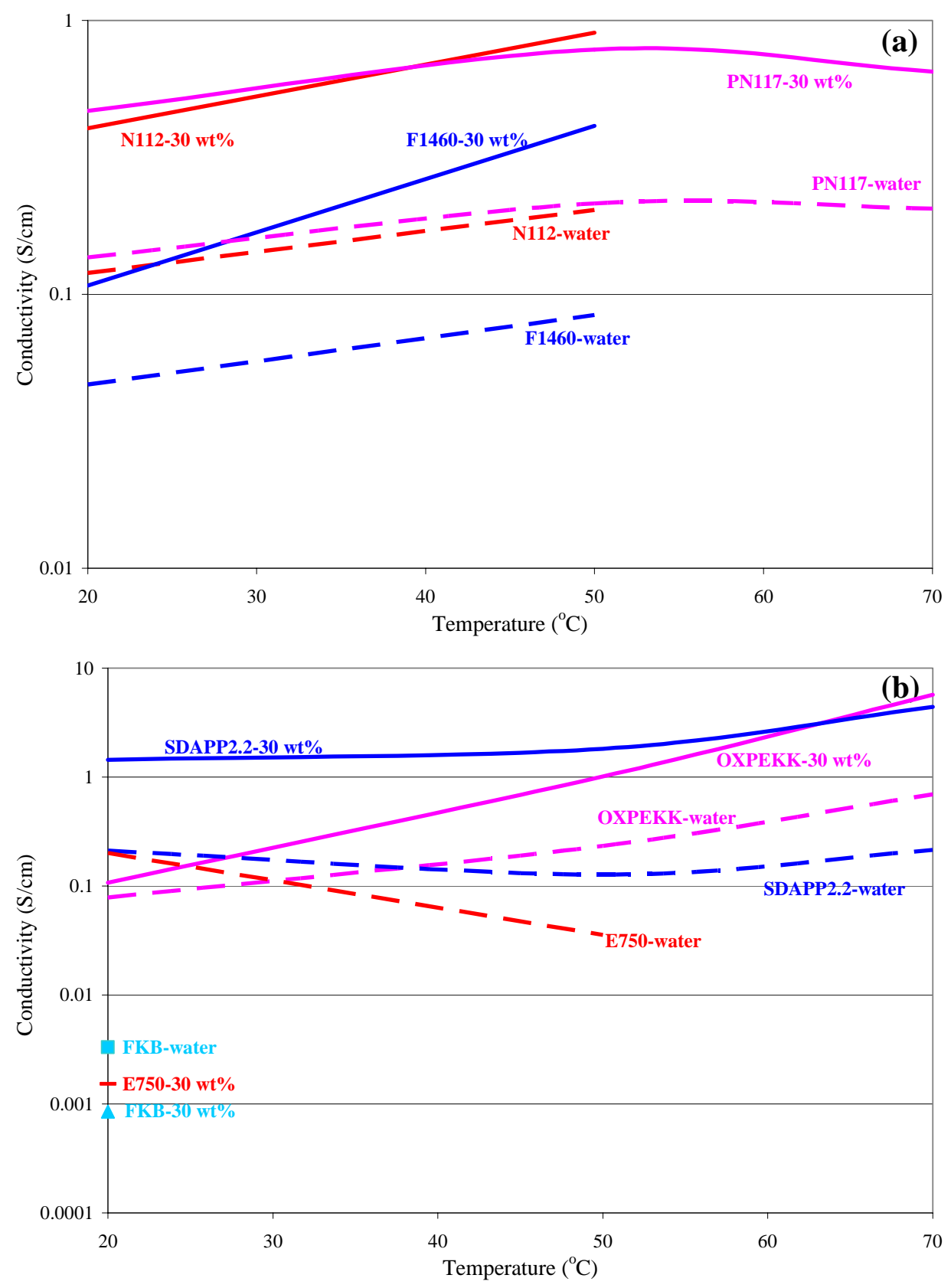

Figure 10. Ionic conductivity of the membrane samples as a function of temperature and acid concentration for (a) fluorocarbon type membranes and (b) hydrocarbon type membranes. 


\subsection{CONCLUSIONS AND RECOMMENDATIONS}

The chemical stability, $\mathrm{SO}_{2}$ transport and ionic conductivity characteristics have been measured for several commercially available and experimental proton-conducting membranes. Commercially available PFSA membranes such as the $\mathrm{Nafion}^{\circledR}$ series exhibited excellent chemical stability and ionic conductivity in sulfur dioxide saturated sulfuric acid solutions. Sulfur dioxide transport in the Nafion ${ }^{\circledR}$ membranes varied proportionally with the thickness and equivalent weight of the membrane. Although the $\mathrm{SO}_{2}$ transport in the Nafion ${ }^{\circledR}$ membranes is higher than desired, the excellent resistivity and chemical stability makes this membrane the best commercially-available membrane at this time.

Initial results indicated that a modified Nafion ${ }^{\circledR}$ membrane incorporating Pt nanoparticles exhibited excellent chemical stability and significantly reduced $\mathrm{SO}_{2}$ transport. Reduced $\mathrm{SO}_{2}$ transport was also measured with commercially available PBI membrane and several experimental membranes produced at SNL and Clemson. These membranes also exhibit good resistivity and stability in concentrated sulfuric acid solutions and, thus, serve as promising candidates for the SDE. Therefore, we recommend further testing of these membranes including electrolyzer testing to determine if the reduced $\mathrm{SO}_{2}$ transport eliminates the formation of sulfur-containing films at the membrane/cathode interface.

$\mathrm{SO}_{2}$ transport measurements in the original characterization cell identified experimental limitations of the original design. During the last quarter of FY08 we redesigned and fabricated a new testing cell to overcome the previous limitations. This cell also offers the capability to test membranes under polarized conditions as well as test the performance of MEAs under selected electrolyzer conditions. 


\subsection{REFERENCES}

[1] P. Sivasubramanian, R. P. Ramasamy, F. J. Freire, C. E. Holland and J. W. Weidner, "Electrochemical Hydrogen Production from Thermochemical Cycles using a Proton Exchange Membrane Electrolyzer”, Int. J. Hydrogen Energy, submitted.

[2] Westinghouse Electric Corporation, "A Study on the Electrolysis of Sulfur Dioxide and Water for the Sulfur Cycle Hydrogen Production Process”, AESD-TME-3043, July 1980.

[3] J. L. Steimke and T. J. Steeper, "Characterization Testing of $\mathrm{H}_{2} \mathrm{O}-\mathrm{SO}_{2}$ Electrolyzer at Ambient Pressure", Westinghouse Savannah River Company, Technical Report WSRC-TR2005-00310, August 1, 2005.

[4] H. L. Tang, M. Pan, S. P. Jiang and R. Z. Yuan, "Modification of NafionTM membrane to reduce methanol crossover via self-assembled Pd nanoparticles", Materials Letters, 2005 (59), pp.3766-3770.

[5] R. Junginger and B. D. Struck, "Separators for the electrolytic cell of the sulfuric acid hybrid cycle”, Int. J. Hydrogen Energy, 1982 (7), pp. 331-340.

[6] C. H. Fujimoto, M. A. Hickner, C. J. Cornelius and D. A. Loy, "Ionomeric Poly(phenylene) Prepared by Diels-Alder Polymerization: Synthesis and Physical Properties of a Novel Polyelectrolyte”, Macromolecules, 2005 (38), pp. 5010-5016. 